\title{
Land use and environmental factors affecting red-legged partridge (Alectoris rufa) hunting yields in southern Spain
}

Received: 30 November 2004 / Accepted: 30 December 2005

(C) Springer-Verlag 2006

\begin{abstract}
The red-legged partridge is a small game species widely hunted in southern Spain. Its commercial use has important socioeconomic effects in rural areas where other agrarian uses are of marginal importance. The aims of the present work were to identify areas in Andalusia (southern Spain) where game yields for the red-legged partridge reach high values and to establish the environmental and land use factors that determine them. We analysed 32,134 annual hunting reports (HRs) produced by 6,049 game estates during the hunting seasons 1993/1994 to 2001/2002 to estimate the average hunting yields of red-legged partridge in each Andalusian municipality $(n=771)$. We modelled the favourability for obtaining good hunting yields using stepwise logistic regression on a set of climatic, topographical, land use and vegetation variables that were available as digital coverages or tabular data applied to municipalities. Good hunting yields occur mainly in plain areas located in the Guadalquivir valley, at the bottom of Betic Range and in the Betic depressions. Favourable areas are related to highly mechanised, lowelevation areas mainly dedicated to intensive dry crops. The most favourable areas predicted by our model are mainly located in the Guadalquivir valley.
\end{abstract}

Keywords Andalusia - Game species · Logistic regression $\cdot$ Management plans $\cdot$ Potential areas

\section{Introduction}

The red-legged partridge (Alectoris rufa Linnaeus, 1758) occurs in southwestern Europe in a large variety of

J. M. Vargas $(\bowtie) \cdot$ J. C. Guerrero · M. A. Farfán

A. M. Barbosa - R. Real

Departamento de Biología Animal,

Facultad de Ciencias,

Universidad de Málaga,

E-29071 Málaga, Spain

e-mail: jmvy@uma.es

Tel.: +34-952-131861

Fax: +34-952-131668
Mediterranean habitats up to elevations of $1,500 \mathrm{~m}$. It shows the highest densities in non-intensive agricultural landscapes scattered with patches of open scrub and medium-high bush cover (Cramp and Simmons 1980; Berger 1987; Lucio and Purroy 1987, 1992a; Peiró et al. 1993; Ballesteros 1998). These agro-systems are still abundant in the Iberian Peninsula, particularly in its southern half (Castilla-La Mancha, Extremadura and Andalusia), where the species probably originated and where its wild populations reach the highest densities within its current distribution range (Herranz et al. 2000; BlancoAguiar et al. 2003). In this territory, the red-legged partridge is the most attractive small game species (Vargas and Muñoz 1996), and its commercial use has important socioeconomic effects in several rural areas where other agrarian uses are only marginally important (LópezOntiveros and García-Verdugo 1991; Delibes 1992; Lucio and Purroy 1992b).

The red-legged partridge has suffered a notable decline in $95 \%$ of its original European range (Aebischer and Potts 1994), especially during the last two decades (Aebischer and Lucio 1997; Rocamora and Yeatman-Berthelot 1999). Several authors pointed out that habitat quality loss and hunting pressure are the two main factors that caused this decline (Ricci 1985; Lucio and Purroy 1992b; Capelo and Castro-Pereira 1996; Borralho et al. 1997; Tapper 1999). In spite of this, restocking and predator control are the most common management tools in Spain (Lucio 1991; Vargas and Duarte 2002), even though restocking of red-legged partridge is not effective to enhance wild populations (Gortázar et al. 2000) and the legal or illegal control of predators is one of the main factors affecting endangered predators in Spain (Villafuerte et al. 1998).

The current situation of the red-legged partridge is of particular concern to environmentalists, game managers and government officials. The uncertainty about the species' future has additional connotations in the autonomous regions of Southern Spain, due to the negative economic effects that a population decline in this profitable game species could bring about. A. rufa has been recently declared a priority species in Castilla-La Mancha. In Andalusia, a regional 
recovery plan for the red-legged partridge was implemented several years ago, which is not giving the expected results due to the lack of necessary scientific advice and financial support.

The recovery of the red-legged partridge is not an easy task, as the problems affecting this species are multi-causal (Vargas and Duarte 2002). Habitat quality is the critical factor determining the distribution and density of its populations, and the correct management of crops and scrubs is critical for maintaining them (Rands 1987; Ricci 1992; Lucio 1998; Vargas 2002). However, the mere management of vegetation does not warrant the preservation of steady nuclei (García et al. 1983; Lucio 1998); on the contrary, the combination of several management measures is needed to fulfil this goal in the long run (Borralho et al. 1997; Lucio 2002). Pépin and Blayac (1990) even stated that a good management of game effort is more important than any other management tool.

Current private initiatives for the recovery of the redlegged partridge lack scientific advice, involve only a scarce participation of qualified technicians and are insufficiently supported by the administrations. It is necessary to work at a regional level, planning macro-spatial actions on wide and environmentally homogeneous surfaces (Vargas 2002; Lucio and Sáenz de Buruaga 2002). Lucio and Sáenz de Buruaga (2002) and Blanco-Aguiar et al. (2003), for example, proposed the creation of protection areas that could act as genetically diverse population sources. In Spain, the first step would be to delimit optimal and suboptimal areas for the species and to identify their causal factors, within each autonomous region, as regional governments hold the exclusive powers regarding game activities.
The aims of the present work were to identify areas in Andalusia (southern Spain) where game yields for the redlegged partridge reach high values and to establish the environmental and land use factors that determine these. Using this information, we forecasted potentially optimal areas for the red-legged partridge in this region, with a view to the future elaboration of species recovery and management plans from an integrated regional perspective.

\section{Materials and methods}

\section{Study area}

Andalusia (S Spain) comprises $87,268 \mathrm{~km}^{2}$ and is administratively divided into 771 municipalities grouped in eight provinces. Medium-sized mountains predominate in the Andalusian landscape, covering $42 \%$ of its total surface. The main mountain ranges are Sierra Morena, along the northern fringe of the region, and the Betic System, sub-divided into two ranges, Sub-Betic and Penibetic, which are NE-SW-oriented and occupy mainly the eastern part of the region. The maximum elevation $(3,479 \mathrm{~m})$ occurs in the Penibetic range. The most important plain is the Guadalquivir valley, which is longitudinally oriented between Sierra Morena and the Betic System (Fig. 1). The climate of this region is Mediterranean, with mild winters and severe summer droughts. There is a decreasing gradient of precipitation from west to east.

Forty-seven percent of the Andalusian surface area is used as agricultural land (Instituto de Estadística de Andalucía 2002). Olive groves $(82 \%$ of the surface destined to
Fig. 1 Study area. Shown in schematic form are the main mountain ranges (Sierra Morena and the Betic System, sub-divided into two ranges, SubBetic and Penibetic) and the most important plain (Guadalquivir valley)

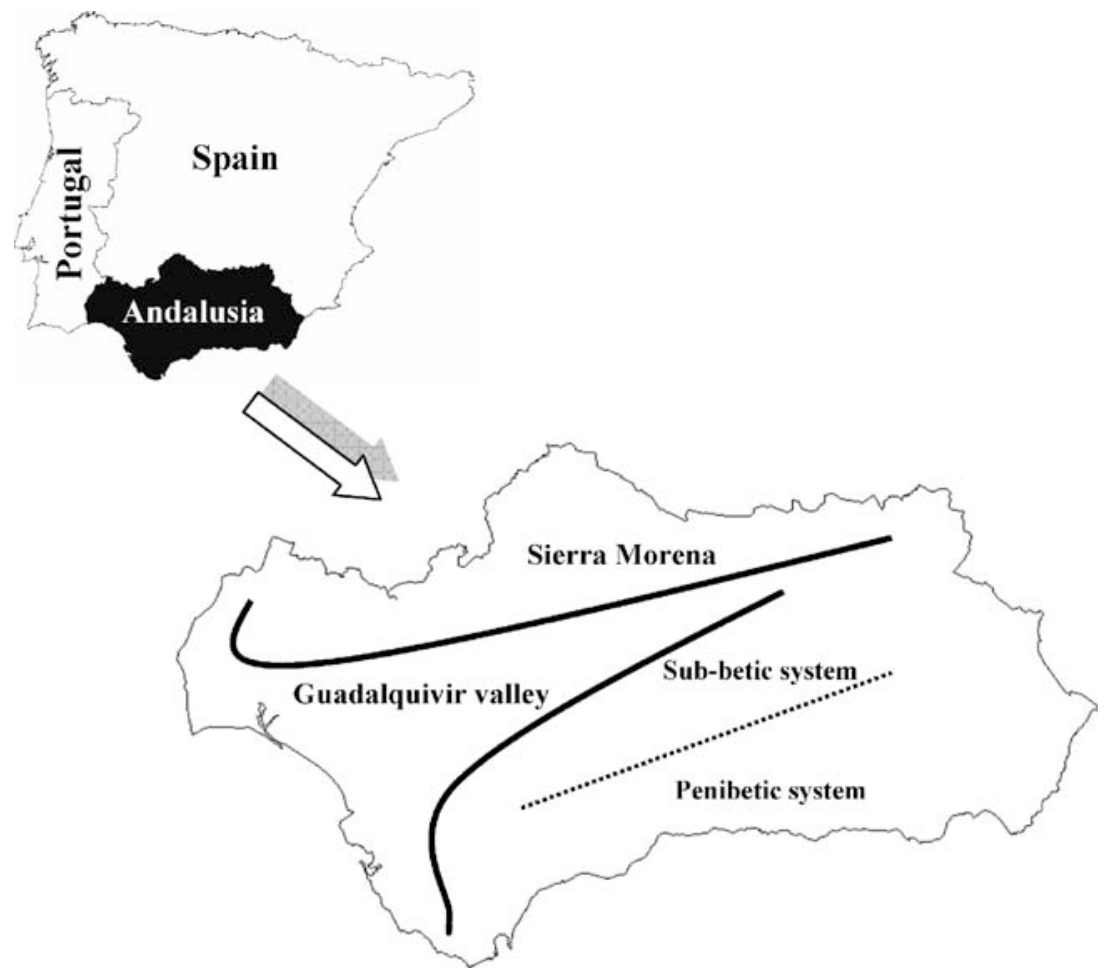


Table 1 Variables used to model the potential distribution of the red-legged partridge hunting yields in Andalusia

\begin{tabular}{|c|c|}
\hline Code & Variable \\
\hline ALTI & Altitude $(\mathrm{m})^{\mathrm{a}}(1)$ \\
\hline SLOP & Slope $(\%)^{\mathrm{a}}$ (calculated from Alti) \\
\hline TEMP & Mean annual temperature $\left({ }^{\circ} \mathrm{C}\right)^{\mathrm{a}}(2)$ \\
\hline TJAN & Mean temperature in January $\left({ }^{\circ} \mathrm{C}\right)^{\mathrm{a}}(2)$ \\
\hline TJUL & Mean temperature in July $\left({ }^{\circ} \mathrm{C}\right)^{\mathrm{a}}(2)$ \\
\hline TRAN & Annual temperature range $\left({ }^{\circ} \mathrm{C}\right)(=\text { TJul }- \text { TJan })^{\mathrm{a}}$ \\
\hline DFRO & $\begin{array}{l}\text { Mean annual number of frost days (minimum } \\
\left.\text { temperature }<0^{\circ} \mathrm{C}\right)^{\mathrm{a}}(2)\end{array}$ \\
\hline INSO & Mean annual insolation (hours/year) ${ }^{\mathrm{a}}(2)$ \\
\hline PET & Mean annual potential evapotranspiration $(\mathrm{mm})^{\mathrm{a}}(2)$ \\
\hline HJAN & $\begin{array}{l}\text { Mean relative air humidity in January at 07:00 } \\
\text { hours }(\%)^{\text {a }}(2)\end{array}$ \\
\hline HJUL & $\begin{array}{l}\text { Mean relative air humidity in July at 07:00 } \\
\text { hours }(\%)^{\mathrm{a}}(2)\end{array}$ \\
\hline HRAN & Annual relative air humidity range $(\%)(=|H J a n-H J u l|)^{\mathrm{a}}$ \\
\hline PREC & Mean annual precipitation $(\mathrm{mm})^{\mathrm{a}}(2)$ \\
\hline PIRR & Pluviometric irregularity ${ }^{\mathrm{a}}(3)$ \\
\hline LATI & Mean latitude $\left({ }^{\circ} \mathrm{N}\right)(4)$ \\
\hline LONG & Mean longitude $\left({ }^{\circ} \mathrm{W}\right)(4)$ \\
\hline SR & Sedimentary rock (\% area) (4) \\
\hline MR & Metamorphic rock (\% area) (4) \\
\hline IR & Intrusive rock (\% area) $(4)$ \\
\hline VR & Volcanic rock (\% area) (4) \\
\hline $\mathrm{S}(<3)$ & Slope lower than $3 \%$ (\% area) (4) \\
\hline$S(3-7)$ & Slope between 3 and $7 \%$ (\% area) (4) \\
\hline $\mathrm{S}(7-15)$ & Slope between 7 and $15 \%$ (\% area) (4) \\
\hline $\mathrm{S}(15-30)$ & Slope between 15 and $30 \%$ (\% area) (4) \\
\hline$S(30-45)$ & Slope between 30 and $45 \%$ (\% area) (4) \\
\hline $\mathrm{S}(>45)$ & Slope higher than $45 \%$ (\% area) (4) \\
\hline $\mathrm{IHC}$ & Irrigated herbaceous crops (\% area) (4) \\
\hline IWC & Irrigated woody crops (\% area) (4) \\
\hline IDC & Intensive dry crops (\% area) $(4)$ \\
\hline EDC & Extensive dry crops (\% area) (4) \\
\hline DWC & Dry wood crops (\% area) (4) \\
\hline OW & Oak wood (\% area) (4) \\
\hline $\mathrm{CW}$ & Conifer wood (\% area) (4) \\
\hline $\mathrm{SC}$ & Scrub (\% area) $(4)$ \\
\hline GSC & Grassland-scrub (\% area) (4) \\
\hline PG & Pasture-grassland (\% area) (4) \\
\hline RW & Riparian wood (\% area) (4) \\
\hline PD & Pig density (individuals/100 ha) (4) \\
\hline SD & Sheep density (individuals/100 ha) (4) \\
\hline $\mathrm{BD}$ & Bovine density (individuals/100 ha) (4) \\
\hline GD & Goat density (individuals/100 ha) (4) \\
\hline FD & Fowl density (individuals /100 ha) (4) \\
\hline ED & Equine density (individuals /100 ha) (4) \\
\hline TD & Tractor density (number of tractors/100 ha) (4) \\
\hline CHD & $\begin{array}{l}\text { Combine-harvester density (number of } \\
\text { combine-harvesters/100 ha) (4) }\end{array}$ \\
\hline PTD & Human population density (individuals/100 ha) (4) \\
\hline $\operatorname{SM}(<5)$ & Smallholding up to 5 ha (4) \\
\hline $\begin{array}{l}\text { SM } \\
(5-10)\end{array}$ & Smallholding between 5 and 10 ha (4) \\
\hline
\end{tabular}

Table1 (continued)

\begin{tabular}{ll}
\hline Code & Variable \\
\hline SM & Smallholding between 10 and 20 ha (4) \\
$(10-20)$ & \\
SM & Smallholding between 20 and 50 ha (4) \\
$(20-50)$ & \\
SM $(>50)$ & Smallholding of more than 50 ha (4) \\
\hline
\end{tabular}

${ }^{\mathrm{a}}$ For these variables, we calculated the minimum value (min), maximum (max), mean (me) and range (ran) for each municipality (1) U. S. Geological Survey (1996), (2) Font (1983), (3) Montero de Burgos y González-Rebollar (1974), (4) SIMA (1996)

woody crops) and cereals ( $48 \%$ of the surface destined to herb crops) are the main crops, both of them fundamentally for dry farming. Thirty-eight percent of the agricultural land is mountainous, with the crops generally restricted to the inner valleys or to hillsides of little slope.

The number of game licences issued annually in Andalusia during the last 15 years averaged more than 250,000 . Game activities are performed in $92.3 \%$ of the territory, and the number of game estates is close to 9,000 , occupying $89.2 \%$ of the Andalusian surface (Guirado and Ortega 2002; Junta de Andalucía 2003a). There are 40 game species, 10 mammals and 30 birds (Junta de Andalucía 2003b).

Methods of capture and hunting yields

Traditionally, three capture methods are legally authorised in Andalusia to hunt partridges: coursing and walked-up shooting, driven shooting and hunting with decoy (Vargas et al. 1997). Coursing and walked-up shooting is done by several hunters, with and without dogs, respectively, walking down in line while maintaining a certain distance between them, flushing out the game and attempting to bring it down. Driven shooting consists in battues that flush out the game and direct it towards a line where the hunters are stationed. Hunting with decoy is practised during the mating period; males are put into a cage, placed in open areas and used as decoy. To establish the relative importance of these methods in determining the hunting yields of red-legged partridge, we used the information contained in the annual hunting reports (AHRs) during the period 1993/1994 to $2001 / 2002$. AHRs, together with Technical Hunting Plans, are mandatory in Andalusia since the beginning of the 1990s for all game estates, which must report all their game activities with the ultimate aim of protecting and fostering their game richness.

We analysed 32,134 AHRs from 6,049 game estates. We used those that reported red-legged hunting to estimate the average hunting yields of this species in each of the 771 
Andalusian municipalities, according to the following expression:

\section{HY}

$=\frac{\sum \text { mean annual number of individuals hunted per game estate }}{\sum \text { areas of the game estates }}$

$* 100$

where $\mathrm{HY}$ is the hunting yield per municipality expressed in number of red-legged partridges captured per 100 ha of game estate.

As the values of game harvest reported in the AHRs may or may not correspond to the actual values, we preferred to estimate the relative position of each municipality in a ranking of favourability for the red-legged partridge. We established six classes of hunting yields using a logarithmic scale among the extreme values obtained in the Andalusian municipalities (Farfán et al. 2004). We considered the three highest classes, that is, those with $\mathrm{HY}>12$, as representative of good yields and the three lowest as poor yields.

\section{Predictive models}

We characterised the municipalities with good yields with respect to those with poor yields using stepwise logistic regression (Hosmer and Lemeshow 1989) on 93 environmental and land use variables (Table 1). Climatic variables (TEMP through PIRR) were digitised using the CartaLinx 1.2 software and processed using the Idrisi32 GIS software (see Barbosa et al. 2003 for a detailed explanation on the digitising methods). Land type and vegetation variables (SR through $\operatorname{SM}(>50)$ ) were available as tabular data and were added directly to the database.

We modelled the favourability for obtaining good hunting yields for the red-legged partridge using the en- vironmental favourability function described by Real et al. (2006), which may be obtained by performing logistic regression of good and poor hunting yields (ones and zeros, respectively) on a series of predictor variables and then eliminating from the model the effect of the uneven proportion of ones and zeros in the data set. The favourability for a good hunting yield in each municipality is obtained from the formula:

$F=(P /(1-P)) /\left(\left(n_{1} / n_{0}\right)+(P /(1-P))\right)$

where $P$ is the probability value given by logistic regression, and $n_{1}$ and $n_{0}$ are the number of municipalities with good and poor hunting yields, respectively (Real et al 2006).

\section{Results}

\section{Methods of capture}

Red-legged partridges are hunted in $91.5 \%$ of Andalusian game estates mostly by coursing, a method used by $48.7 \%$ of the game estates with no particular geographic trend, to capture $60.9 \%$ of the partridges hunted in Andalusia in the period 1993/1994-2001/2002. In the same period, hunting with decoy was used in $43.4 \%$ of the game estates to hunt $19.8 \%$ of the red-legged partridges captured. In some mountainous areas, this is the only hunting method used as both coursing and driven shooting are incompatible with the big game practice, the principal game activity in these areas. The least used method of capture for this species is driven shooting $(7.9 \%$ of the game estates and $19.3 \%$ individuals hunted), which is mainly used in the plain areas of western Andalusia, where beatings are performed in $29.9 \%$ of the game estates in Cadiz province and in $19.8 \%$ of the estates in Seville province.
Fig. 2 Red-legged partridge hunting yield distribution in the municipalities of Andalusia. White areas correspond to zones with poor hunting yields while darker areas are zones with good hunting yields, divided into three classes. Black lines correspond to province limits

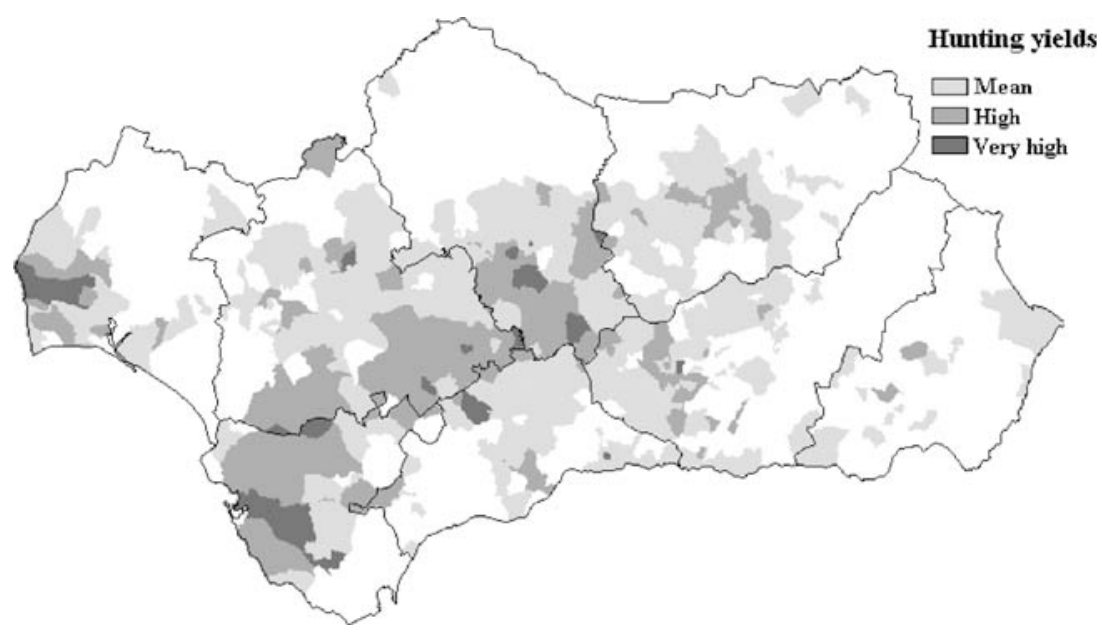


Fig. 3 Evolution of the hunting yield favourability model during the first three steps of the logistic regression and final model (step 7). 0 represents minimum and 1 represents maximum favourability; $r$ is Pearson's correlation coefficient between the favourabilities predicted in each step and those of the final model $(n=771, p<0.001)$
Step 1: $\mathbf{r}=\mathbf{0 . 7 5 5}$

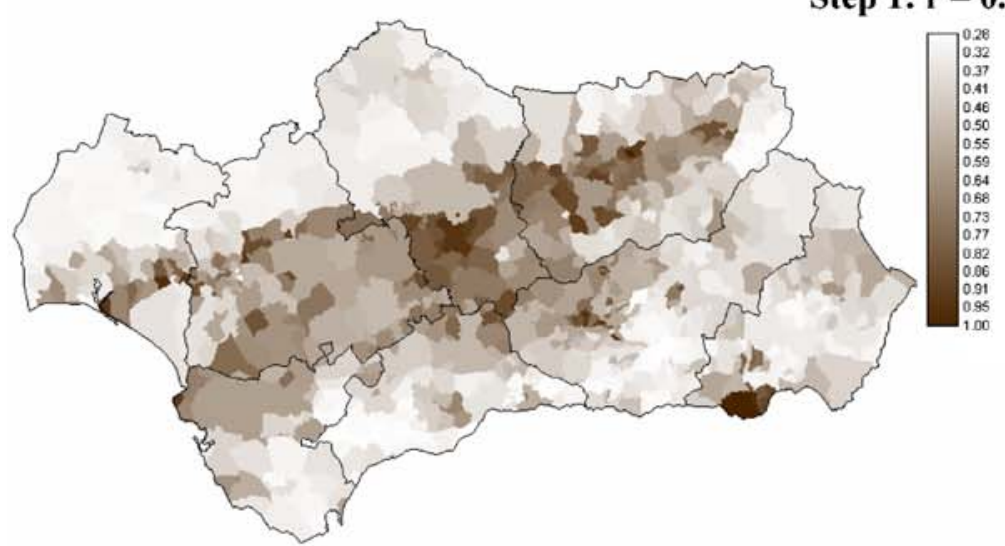

Step 2: $\mathbf{r}=\mathbf{0 . 8 3 9}$

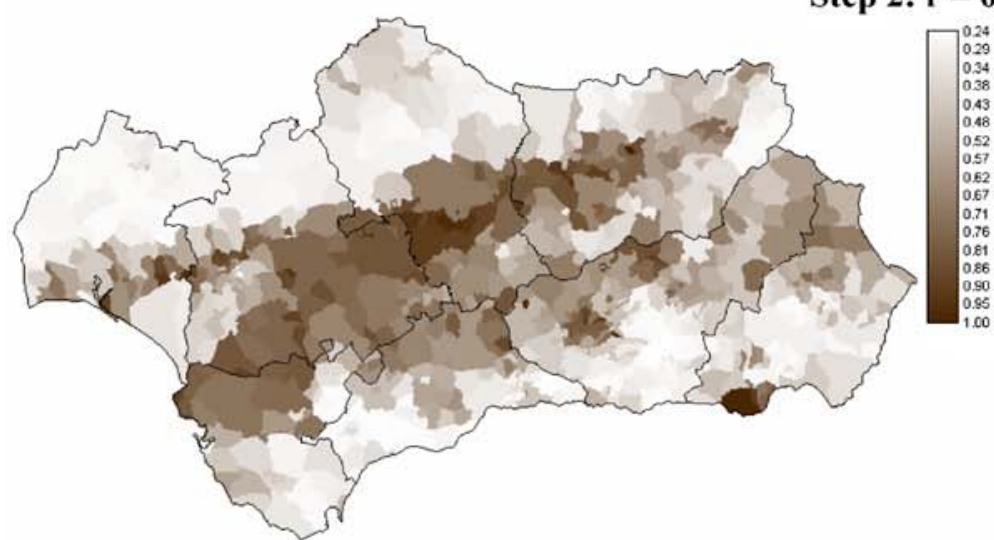

Step 3: $\mathbf{r}=\mathbf{0 . 9 1 9}$

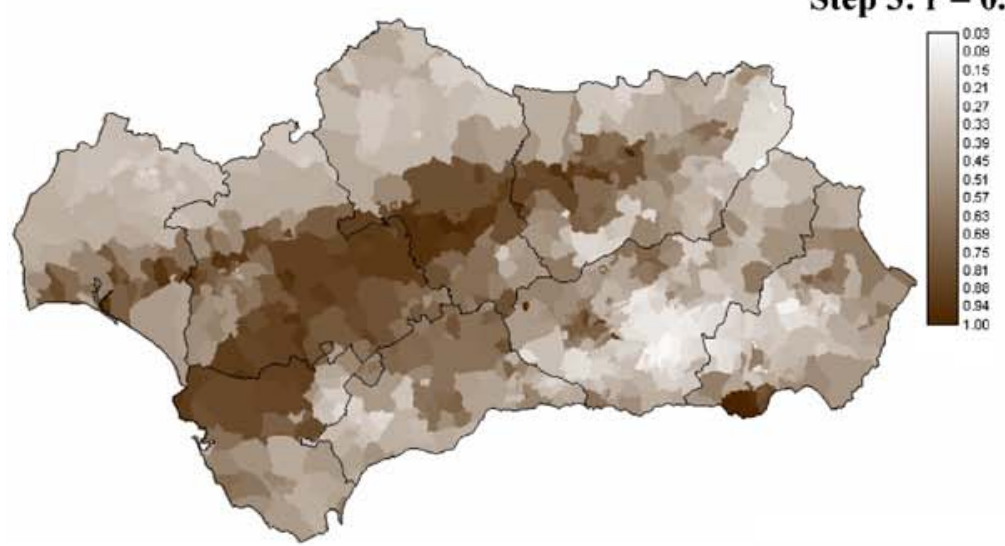

Step 7: Final model

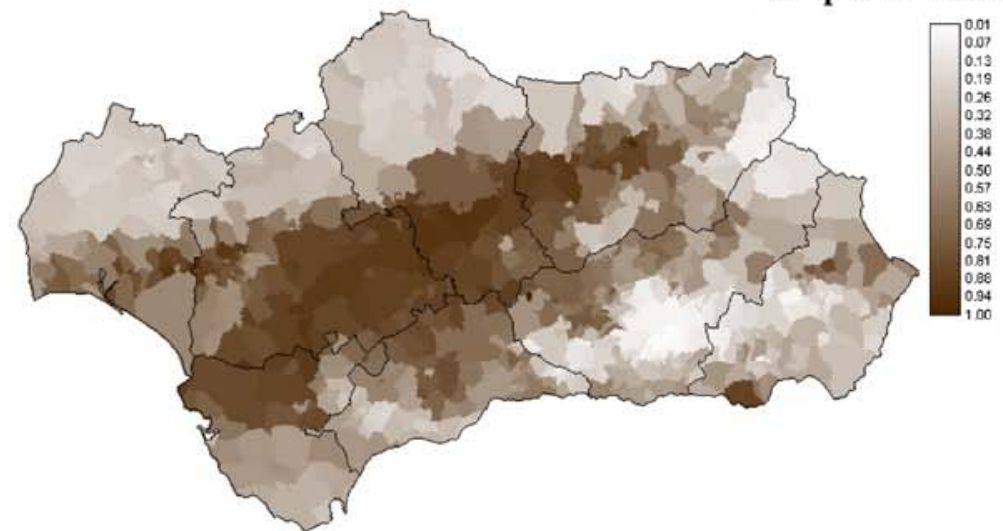


Table 2 Variables and their coefficients $(\beta)$ selected by stepwise logistic regression to predict the distribution of the hunting yields of the red-legged partridge

\begin{tabular}{lc}
\hline Variable & Coefficient $(\beta)$ \\
\hline Tractor density (number of tractors/100 ha) & 0.284 \\
Intensive dry crops (\% area) & 0.022 \\
Minimum altitude (m) & -0.002 \\
Dry wood crops (\% area) & 0.014 \\
Sedimentary rock (\% area) & 0.008 \\
Maximum annual relative air humidity range (\%) & 0.072 \\
Maximum mean annual number of frost days & -0.024
\end{tabular}

The variables are ranked according to their order of entrance in the model

\section{Hunting yields}

The hunting yield distribution of the red-legged partridge in Andalusia is represented in Fig. 2. Good hunting yields occur mainly in plain areas located in the Guadalquivir valley, at the bottom of the Betic Range and in the Betic depressions.

\section{Predictive models}

The most favourable areas for red-legged partridge hunting yields are mainly located in the Guadalquivir valley, as it is shown in the final model represented in Fig. 3. The evolution of the model shows that more than $80 \%$ of its final predictive capacity is reached in the third step (Fig. 3), which points out the high capacity of this partial model to explain parsimoniously the distribution of good hunting yields using only three variables. These three first variables included in the logistic regression model (Table 2) indicate that favourable areas occur in highly mechanised, lowelevation areas dedicated to intensive dry crops.

\section{Discussion}

The red-legged partridge is the most wanted small game species in the Iberian Peninsula both for national and foreign hunters (METRA SEIS 1985; López-Ontiveros and García-Verdugo 1991; Fontoura 1992; Garrido 2002). In Spain, it is reported as a breeding species in $86.3 \%$ of the universal transverse mercator $10 \times 10 \mathrm{~km}^{2}$, although its density tends to be higher in the southern half of the country (Blanco-Aguiar et al. 2003). Density and hunting yield are not always equivalent parameters (Lucio 1991), but when relative abundance values per unit area are lacking, hunting yields provide a quite realistic image of both the potential and the actual good and poor areas. In the case of Andalusia, hunting yields declined from 14 partridges/100 ha in 1985 (Delibes 1992) to eight to nine partridges/100 ha in 1995 (Vargas and Muñoz 1996; Junta de Andalucía 1997), which implies that, after a decade, the captures had diminished by $42.2 \%$. However, during the recent years, a rebound of captures took place (Garrido 2002) due to the increase in restocking with red-legged partridges bred in farms, which represent more than a third (about 350,000 ) of the individuals brought down each season (Vargas 2002). This increase has not contributed to the demographic recovery of the species, which keeps undergoing a progressive decline throughout the country (Blanco-Aguiar et al. 2003).

The steady decline in hunting yields is not the consequence of an increased hunting pressure, which actually decreased sharply in the last 10 years. In Andalusia, the number of hunting licences decreased by about 60,000 between 1993 and 2003 (Junta de Andalucía 1995, 2004).

This study shows that, currently, the good hunting yields in Andalusia are obtained in the municipalities located along the Guadalquivir valley, mainly in the lower and middle basin, and in the plains between the Sub-Betic and Penibetic ranges. These yields are linked to the existence of wide croplands at low-elevation areas, where the main crops are both herbaceous and woody on dry land and highly mechanised (Table 2).

All the selected variables correlate with croplands. The red-legged partridge selects croplands probably because food is abundant, with a marked preference for crop patches delimited by natural hedge or limiting with areas of open scrubs where they find the appropriate cover to breed (Rands 1986; Ricci et al. 1990; Meriggi et al. 1991). However, the intensification of agriculture in Spain during the last 40 years has considerably altered this landscape, which is one of the main causes of the demographic decline of the red-legged partridge (Vargas 2002). This intensification has brought about an increasing mechanisation that disturbs breeding partridges, smallholding mergers that resulted in the loss of edges, an increase in irrigated lands that are avoided by partridges and the abuse of phytosanitary products that decreases the availability of insects for the chicks (Junta de Andalucía 1995, 1996).

Marginal mountainous agriculture has lost prominence in favour of a more intensive exploitation of plains and open country. However, $38 \%$ of the Andalusian agricultural land is still mountainous and concentrates mainly in the inner depression and hillsides with little slope $(\mathrm{BSCH}$ 2000). It is there, precisely, that good hunting yields are obtained and predicted for the red-legged partridge within the southern fringes of both Sierra Morena and the SubBetic Range.

These results should be considered in future management plans to create protected areas that could act as population sources and contribute to maintain the genetic diversity of the red-legged partridge in Andalusia (BlancoAguiar et al. 2003). In areas outside of these, the possibility of success is more uncertain and expensive because they are woodlands with high density of trees and/or scrub. In fact, red-legged partridges avoid woods and brushwood (Lucio et al. 1996) as they suffer important losses of nests, chicks and breeding females in direct proportion to landscape homogeneity (Duarte and Vargas 2002 and references cited therein). 
Acknowledgements A.M.B. is supported by a doctoral grant from Fundação para a Ciência e a Tecnologia, Portugal.

\section{References}

Aebischer N, Lucio A (1997) Red-legged partridge (Alectoris rufa). In: Hagemeijer EJM, Blair MJ (eds) The EBBC atlas of European breeding birds: their distribution and abundance. Poyser, London, pp 208-209

Aebischer NJ, Potts GR (1994) Red-legged partridge Alectoris rufa. In: Tucker GM, Heath MF (eds) Birds in Europe: their conservation status. BirdLife International, Cambridge, pp 214-215

Ballesteros F (1998) Las especies de caza en España. Biología, ecología y conservación. Estudio y Gestión del Medio, Colección técnica, Oviedo

Barbosa AM, Real R, Olivero J, Vargas JM (2003) Otter (Lutra lutra) distribution modeling at two resolution scales suited to conservation planning in the Iberian Peninsula. Biol Conserv 114:377-387

Berger F (1987) Contribution a l'étude du rôle des haies pour la perdrix rouge (Alectoris rufa). Gibier Faune Sauvage 4:67-81

Blanco-Aguiar JC, Virgós E, Villafuerte R (2003) Perdiz roja, Alectoris rufa. In: Martí R, del Moral JC (eds) Atlas de las aves reproductoras de España. Dirección General de Conservación de la Naturaleza-Sociedad Española de Ornitología, Madrid, pp 212-213

Borralho R, Rego F, Vaz-Pinto P (1997) Demographic trends of redlegged partridge (Alectoris rufa) in Southern Portugal after implementation of management actions. Gibier Faune Sauvage 14:585-600

$\mathrm{BSCH}$ (2000) Los árboles en el espacio agrario. Importancia hidrológica y ecológica. Servicio Agrario y Medioambiental$\mathrm{BSCH}$, Madrid

Capelo M, Castro-Pereira D (1996) Sobrevivência e dispersão de perdizes (Alectoris rufa L.) largadas em duas operaçoes de repovamento cinegético. Rev Florest 9:243-253

Cramp S, Simmons KEL (eds) (1980) Handbook of the birds of Europe, the Middle East and North Africa. The birds of the Western Palearctic, vol 2. Oxford Univ. Press, Oxford

Delibes J (1992) Gestión de los cotos de perdiz roja. In: Fundación "La Caixa" (ed) La perdiz roja. Gestión del hábitat. Fundación "La Caixa", Barcelona, pp 141-146

Duarte J, Vargas JM (2002) Los sumideros de perdiz roja a lo largo del ciclo anual. In: Lucio A, Sáenz de Buruaga M (eds) Aportaciones a la gestión sostenible de la caza en España. FEDENCA-EEC, Madrid, pp 55-71

Farfán MA, Guerrero JC, Real R, Barbosa AM, Vargas JM (2004) Caracterización del aprovechamiento cinegético de los mamíferos en Andalucía. Galemys 16:41-59

Font I (1983) Atlas climático de España. Instituto Nacional de Meteorología, Madrid

Fontoura AP (1992) Importance socio-économique de la chasse à la perdrix rouge (Alectoris rufa) au Portugal. In: Birkan M, Potts GR, Aebischer NJ, Dowell SD (eds) Perdix VI. First international symposium on partridge, quails and francolin. Gibier Faune Sauvage 9:871-878

García A, Gauville G, Landry P, Lartiges A (1983) Influence des aménagements généralement préconisés sur une population de perdrix rouges (Alectoris rufa). Bull Mens Off Natl Chasse 62:9-23

Garrido JL (2002) Capturas de perdiz roja. In: Lucio A, Sáenz de Buruaga M (eds) Aportaciones a la gestión sostenible de la caza en España. FEDENCA-EEC, Madrid, pp 141-147

Gortázar C, Villafuerte R, Martín M (2000) Success of traditional restocking of red-legged partridge for hunting purposes in areas of low density of northeast Spain Aragón. Z Jagdwiss 46:23-30

Guirado J, Ortega F (2002) La caza como actividad de desarrollo sostenible. Medio Ambiente 41(16):22-26
Herranz J, Yanes M, Suárez F (2000) Relaciones entre la abundancia de las especies de caza menor, sus depredadores y la estructura del hábitat en Castilla-La Mancha (España). Ecología 14:219-233

Hosmer DW, Lemeshow S (1989) Applied logistic regression. Wiley, New York

Instituto de Estadístico de Andalucía (2002) Anuario estadístico de Andalucía. Junta de Andalucía, Sevilla

Junta de Andalucía (1995) Medio Ambiente en Andalucía. Informe 1994. Junta de Andalucía, Sevilla

Junta de Andalucía (1996) Medio Ambiente en Andalucía. Informe 1995. Junta de Andalucía, Sevilla

Junta de Andalucía (1997) Medio Ambiente en Andalucía. Informe 1996. Junta de Andalucía, Sevilla

Junta de Andalucía (2003a) Informe Medioambiental 2001. http:// www.juntadeandalucia.es

Junta de Andalucía (2003b) Ley 8/2003 de 28 de octubre de la flora y la fauna silvestres. Consejería de Medio Ambiente. Junta de Andalucía, Sevilla

Junta de Andalucía (2004) http://www.juntadeandalucia.es/medio ambiente/cazaypesca

López-Ontiveros A, García-Verdugo FJ (1991) Geografía de la caza en España. Agric Soc 58:81-112

Lucio A (1991) Ordenación y gestión en caza menor. In: Fuentes A, Sánchez I, Pajuelo L (eds) Manual de ordenación y gestión cinegética. IFEBA, Badajoz, pp 219-255

Lucio A (1998) Recuperación y gestión de la perdiz roja en España. In: FEDENCA/Grupo Editorial V (eds) La perdiz roja. I Curso. Grupo editorial V (FEDENCA), Madrid, pp 63-90

Lucio A (2002) Caza y conservación de la naturaleza. Nuevas tendencias en ordenación cinegética. In: Lucio A, Sáenz de Buruaga M (eds) Aportaciones a la gestión sostenible de la caza en España. FEDENCA-EEC, Madrid, pp 295-312

Lucio A, Purroy FJ (1987) Selección de hábitat de la perdiz roja (Alectoris rufa) en la llanura cerealista del SE de León. Actas I Congreso Internacional de aves esteparias, pp 339-348

Lucio A, Purroy FJ (1992a) Red-legged partridge (Alectoris rufa) habitat selection in northwest Spain. Gibier Faune Sauvage 9:417-429

Lucio A, Purroy FJ (1992b) Caza y conservación de aves en España. Ardeola 39:85-98

Lucio A, Purroy FJ, Sáenz de Buruaga M (1996) Consecuencias del abandono agroganadero en áreas de montaña para la conservación y aprovechamiento cinegético de las perdices roja y pardilla en España. Rev Florest 9:305-318

Lucio A, Sáenz de Buruaga M (2002) La perdiz roja en España. Directrices para su recuperación y gestión. In: Lucio A, Sáenz de Buruaga M (eds) Aportaciones a la gestión sostenible de la caza en España. FEDENCA-EEC, Madrid, pp 127-140

Meriggi A, Montagna D, Zacchetti D (1991) Habitat use by partridges (Perdix perdix and Alectoris rufa) in an area of northern Apennines, Italy. Boll Zool 58:85-90

METRA SEIS (1985) Turismo cinegético en España. Secretaría General de Turismo. Ministerio de Transportes, Turismo y Comunicaciones, Madrid

Montero de Burgos JL, González-Rebollar JL (1974) Diagramas bioclimáticos. ICONA, Madrid, pp 45-48

Peiró V, Seva E, Almiñana M (1993) Selección de hábitat de una población de perdiz roja (Alectoris rufa) en una zona de sierra del sur de la provincia de Alicante. Mediterr (Ser Biol) 14:5-22

Pépin D, Blayac J (1990) Impacts d'un améganement de la garrigue et de l'instauration d'un plan de chasse sur la démographie de la perdrix rouge (Alectoris rufa) en milieu méditerranéen. Gibier Faune Sauvage 7:145-158

Rands MRW (1986) Effect of hedgerow characteristics on partridge breeding densities. J Appl Ecol 23:479-487

Rands MRW (1987) Hedgerow management for the conservation of partridges. Biol Conserv 4:127-139 
Real R, Barbosa AM, Vargas JM (2006) Obtaining environmental favourability functions from logistic regression. Environ Ecol Stat (in press)

Ricci JC (1985) Influence de l'organisation sociale et de la densité sur les relations spatiales chez la perdrix rouge. Conséquences démographiques et adaptatives. Rev Ecol (Terre Vie) 40:53-85

Ricci JC (1992) Situación de la perdiz roja en Francia. Gestión y reconstitución de las poblaciones. Nidificación y predación. In Fundación "La Caixa" (ed) La perdiz roja. Gestión del hábitat. Fundación "La Caixa", Barcelona, pp 117-139

Ricci JC, Mathon JF, García A, Berger F, Esteve JP (1990) Effect of habitat structure and nest site selection on nest predation in redlegged partridge (Alectoris rufa L.) in French Mediterranean farmlands. Gibier Faune Sauvage 7:231-253

Rocamora G, Yeatman-Berthelot D (1999) Oiseaux menacés et à surveiller en France. Listes rouges et recherches de priorités. Societé d'Études Ornithologiques de France/Ligue pour la Protection des Oiseaux, Paris

SIMA (Sistema de Información Municipal de Andalucía) (1996) Instituto Estadístico de Andalucía. Junta de Andalucía, Sevilla
Tapper SC (ed) (1999) A question of balance. Game animals and their role in the British countryside. The Game Conservancy Trust, Fordingbridge, UK

U. S. Geological Survey (1996) GTOPO30. Land Processes Distributed Archive Center, http://edcdaac.usgs.gov/gtopo30/gtopo30.asp

Vargas JM (2002) Alerta cinegética. Reflexiones sobre el futuro de la caza en España. Otero, Madrid

Vargas JM, Duarte J (2002) Dos modelos discrepantes de gestión de la perdiz roja en España. In: Lucio A, Sáenz de Buruaga M (eds) Aportaciones a la gestión sostenible de la caza en España. FEDENCA-EEC, Madrid, pp 93-119

Vargas JM, Díaz P, Rendón MA, Lorenzo FG, Buenestado C, Cardo M (1997) Manual del cazador en Andalucía. Egmasa, Sevilla

Vargas JM, Muñoz AR (1996) Panorámica de la caza menor en Andalucía. In: Federación Andaluza de Caza (ed) La caza en Andalucía y su problemática. Federación Andaluza de Caza, Archidona, pp 1-19

Villafuerte R, Viñuela J, Blanco JC (1998) Extensive predator persecution caused by population crash in a game species: the case of red kites and rabbits in Spain. Biol Conserv 84:181-188 